\title{
Penyelesaian Non-Prosekutorial Dan Rekonsiliatif Terhadap Pelanggaran Hak Asasi Manusia Yang Berat
}

\author{
Ifdhal Kasim \\ Jl. Latu Harhari 4 B Menteng Jakarta Pusat \\ devi_ruliati@komnasham.go.id
}

\begin{abstract}
Today, the Criminal Court Procedure is not the sole mechanism to put the responsibiliy for the serious violence against human rights. The Truth and Reconciliation Commission (KKR) which has been developed is considered to be another procedure to overcome national problems, and also is expected to respond individual injustice among the victims.
\end{abstract}

Keywords: Human rights, reconsiliation, Rekonsiliasi, Truth and Reconciliation Commission

\section{Pendahuluan}

Dalam tiga dekade belakangan ini telah terjadi pergeseran paradigma -yang masih terus berjalan, terhadap kebutuhan akan pertanggungjawaban (accountability) dan dalam usaha menghadapi masa lalu yang represif pada suatu negara. Kalau pada waktu lalu para diplomat dan negosiator mengabaikan isu pelanggaran hak asasi manusia yang telah terjadi karena dianggap sebagai penghalang terhadap stabilitas dan penyelesaian konflik, maka sekarang isu yang diabaikan tersebut dianggap sebagai bagian integral dan tak terpisahkan dalam menempuh perdamaian. Sebagai contoh, meskipun kesepakatan penghentian perang saudara di El Salvador, Bosnia dan Guatemala masing-masing memiliki kelemahannya dari sudut pertanggungjawaban, tetapi sebenarnya masing-masing mencerminkan pergeseran paradigma tersebut. Yakni dengan memasukkan berbagai mekanisme dalam usaha menyikapi pelanggaran hak asasi manusia yang berat di masa lalu, dan mengakui bahwa perdamaian yang langgeng tak mungkin dicapai tanpa adanya mekanisme pertanggungjawaban tersebut. 
Dalam setengah abad terakhir ini di berbagai negara telah mengemuka dengan pesat perkembangan sejumlah mekanisme pertanggungjawaban pelanggaran hak asasi manusia yang berat. Pengadilan pidana bukan lagi dianggap sebagai satu-satunya mekanisme menagih pertanggungjawaban atas pelanggaran hak asasi manusia yang berat. Telah tumbuh dan berkembang mekanisme lain di luar mekanisme prosekutorial, seperti pertanggungjawaban historis dengan membentuk Komisi Kebenaran dan Rekonsiliasi, lustration atau sanksi non-pidana, dan pengadilan hybrida. ${ }^{1}$ Tulisan ini akan membahas mekanisme non-prosekutorial tersebut, terutama berkaitan dengan Komisi Kebanaran dan Rekonsiliasi dan sanksi non-pidana (lustration). Di samping itu, tulisan ini akan meninjau efektivitas beberapa pendekatan tersebut.

\section{Mekanisme Sanksi Non-Pidana (Lustration)}

Dalam praktik semua kasus pelanggaran hak asasi manusia yang berat (yang biasanya bersifat massif), pertanggungjawaban melalui pengadilan pidana seringkali harus bersifat selektif. Pelanggaran dengan korban yang massal itu biasanya hanya dilakukan oleh sejumlah besar orang. Mengadili semua pelaku (mulai dari perencana, pemberi perintah hingga kepada pelaku langsung) - ditambah lagi semua yang bekerja sama dengan mereka - secara politis dapat menimbulkan ketidakstabilan politik, memecah belah masyarakat, dan secara logistik maupun ekonomi teramat sulit dilakukan. Sebagai akibatnya adalah, masyarakat yang demikian kemudian memilih menggunakan pendekatan 'lustration' (sanksi nonpidana) dalam menyelesaikan masa lalu mereka yang kelam itu.

Yang dimaksud dengan lustration adalah pemutihan dengan penghentian dini seseorang dari jabatannya. Karena jabatan yang dipegang oleh seseorang pada rezim yang lalu, atau karena implikasi atau perannya dalam sistem penindasan, seseorang bisa dicegah memegang

${ }^{1}$ Prof. M. Cherif Bassioni menunjukkan dengan analisis yang tajam dari sudut hukum internasional tentang tanggungjawab negara dalam memenuhi kewajiban internasionalnya bila terjadi pelanggaran serius hak asasi manusia, dan pertanggungjawaban itu dapat dilakukan dalam bentuk: (a) pengadilan internasional; (b) inquiri internasional dan nasional; (c) komisi kebenaran; (d) pengadilan nasional; (e) lustrasi; (f) tuntutan perdata; dan (g) pemulihan bagi korban. Lihat tulisannya, "Accountability for Violations of International Humanitarian Law and Other Serious Violations of Human Rights", dalam M. Cherif Bassioni, PostConflict Justice (New York: Transnational Publishers, 2002), hlm. 3-54. 
jabatan-jabatan penting pada pemerintahan yang baru. Mereka juga bisa dilarang memegang jabatan penting di luar sektor pemerintahan - yang bisa memiliki pengaruh pada masyarakat (mencakup jabatan senior di industri perbankan, pers hingga sebagai guru) - tergantung pada situasi negara yang bersangkutan. Pencegahan demikian biasanya bersifat sementara, memungkinkan masa "pemutihan" untuk membangun kembali kepercayaan pada institusi tersebut sebelum mengizinkan orang-orang yang terlibat dalam rezim lama untuk berpartisipasi kembali.

Banyak contoh yang bisa dirujuk negara yang memilih mekanisme lustrasi tersebut. Di Republik Czek, Lithuania dan Jerman pasca-komunis, pembersihan administratif dilakukan untuk mencopot mereka yang terkait dengan pelanggaran di masa lalu dari berbagai jabatan publik untuk sementara waktu, terutama mereka yang diduga bekerja sama dengan polisi rahasia. Di Perancis pasca-perang, proses "epurasi" mempengaruhi puluhan ribu orang. Hampir 1.000 politisi, 6 ribu guru dan 500 diplomat dituduh bekerja sama dengan rezim Vichy. Tidak hanya mereka yang memiliki posisi pemerintahan yang terpengaruh, namun juga mereka yang berada di sektor lainnya. Komisi pembersihan yang terpisah dibentuk untuk para penulis, komposer, seniman, pers dan penghibur, sebagai contoh. Pemerintah Italia mencopot sekitar 1.600 pegawai pemerintah dalam proses "epurasi." Proses pertanggungjawaban yang diadakan oleh pemerintah Yunani setelah adanya pelanggaran yang dilakukan junta militer pada masa 1967-1974, selain mengadili lebih dari 400 mantan perwira atau anggota militer, juga mencopot hampir 100 ribu orang dari posisinya.

Sebuah ketentuan dalam Kesepakatan Dayton yang kurang terkenal dan kurang diperhatikan adalah pembangunan kepercayaan yang mensyaratkan semua pihak untuk segera mengadakan "pengadilan, pencopotan atau pemindahan, sebagaimana diperlukan, terhadap anggota militer, paramiliter dan kepolisian, dan pegawai lainnya, yang bertanggung jawab terhadap pelanggaran serius hak-hak mendasar anggota etnik atau minoritas" ${ }^{2}$

Perlu diperhatikan bahwa ketentuan untuk pertanggungjawaban ini meliputi jauh lebih banyak orang daripada yang diselidiki oleh komisi penyelidik kejahatan perang. Situasi ini mengakui sebuah realitas yang sederhana: meskipun tidak perlu atau tidak mungkin untuk mengadili

${ }^{2}$ Kesepakatan Umum tentang Perdamaian di Bosnia dan Herzegovina, 14 Desember 1995, Lampiran 7, pasal I, paragraf 3(e), dalam 35 ILM 75, 137. 
semua pelaku pelanggaran, bagaimana seorang anggota masyarakat akan merasa aman apabila misalnya salah satu anggota polisi setempat yang menyiksa anaknya atau yang memperkosa istrinya masih bebas? Bagaimana para pengungsi yang berencana kembali bisa percaya pada rezim yang baru apabila kepala desa yang pernah ikut membakar habis rumah-rumah mereka dalam usaha pembersihan etnis tak tersentuh hukum sama sekali?

Meskipun mekanisme pertanggungjawaban sanksi non-pidana banyak diterapkan, mekanisme ini kurang dianalisis dan dievaluasi secara ilmiah. Sebagai contoh, sementara terdapat banyak perhatian internasional pada Komisi Kebenaran Internasional di El-Salvador, kurang terdapat perhatian terhadap badan pertanggungjawaban pelanggaran hak asasi manusia di negara itu. "Komisi Ad Hoc" yang dibentuk sebagai hasil kesepakatan perdamaian, yang beranggotakan tiga warga sipil El-Salvador, meninjau catatan hak asasi manusia para perwira militer, dan dalam sebuah laporan rahasia kepada presiden dan sekretaris jenderal PBB, menyarankan pencopotan atau penurunan jabatan lebih dari 100 perwira -termasuk menteri pertahanan dan wakilnya - atas keterlibatan mereka dalam pelanggaran di masa lalu. Penerapan saran-saran ini berarti tingkat pertanggungjawaban yang lebih besar daripada yang semula dipikirkan oleh warga El Salvador.

Jelas bahwa sanksi non-pidana akan tetap dipergunakan. Jika digunakan dengan tepat, sanksi non-pidana bisa menjalankan beberapa fungsi penting. Sanksi non-pidana memungkinkan pemrosesan jumlah kasus yang amat besar. Sanksi non-pidana bisa memberikan perasaan keadilan dan pertanggungjawaban kepada masyarakat, dan menciptakan keyakinan lebih besar akan kredibilitas institusi dan orang-orang pada rezim yang baru. Pendekatan ini memberikan kesadaran bagi para korban bahwa mereka yang bertanggungjawab atas penderitaan mereka tidak akan dibiarkan berada pada jabatan mereka.

Namun kelemahan paling mencolok dari pendekatan ini adalah penerapannya yang tidak adil. Mereka yang terkait dengan pelanggaran di masa lalu jarang diproses secara benar-benar adil. Karena sifatnya, pencopotan administratif cenderung berskala besar dan mengabaikan prosedur hukum sebagaimana diterapkan pada mereka yang diadili. Karena metode yang kurang terbuka dan kurang formal, proses pencopotan juga rentan terhadap manipulasi untuk kepentingan politik rezim yang baru, untuk mengkonsolidasikan kekuatannya. Terakhir, bila 
diterapkan terlalu luas, pembersihan demikian bisa menciptakan suatu elemen masyarakat yang besar, terbuang dan tidak memiliki pekerjaan, yang pada akhirnya dapat menimbulkan ketidakstabilan.

Dalam laporan akhirnya tentang masalah impunitas pelaku pelanggaran hak asasi manusia, Louis Joinet menyatakan bahwa dalam masyarakat yang mengalami pelanggaran di masa lalu, para pejabat “dengan kekuasaan untuk membuat keputusan yang penting dan dengan demikian memiliki loyalitas pada proses yang sedang berjalan - terutama dalam angkatan bersenjata, polisi dan peradilan - bisa dicopot dari jabatannya, dipindahkan, diturunkan pangkatnya, dipensiunkan lebih awal atau dipecat". ${ }^{3}$ Prinsip Joinet ini menimbulkan banyak pertanyaan tentang penggunaannya secara tepat dan batasannya.

\section{Mekanisme Komisi Kebenaran}

Dalam tiga dekade terakhir, beberapa negara yang berusaha menyelesaikan warisan kekejaman di masa lalu telah membentuk komisi penyelidikan atau biasa disebut Komisi Kebenaran, yang biasanya beranggotakan tokoh masyarakat yang bertugas untuk menyelidiki pelanggaran hak asasi manusia di bawah rezim lama (atau dalam perang saudara) dan menyusun sejarah resmi pelanggaran tersebut. Di negara tersebut, apa yang terjadi sebetulnya secara umum sudah diketahui; yang dilakukan Komisi Kebenaran adalah memberikan pengakuan resmi terhadap pelanggaran tersebut oleh badan resmi yang dianggap sah dan tidak memihak, oleh kalangan domestik maupun internasional.

Komisi Kebenaran bukanlah pengganti pengadilan - dan juga tidak memberikan standar prosedural yang sama dengan pengadilan - namun bisa menjalankan banyak fungsi yang serupa, seperti: (i) memberikan mandat dan otoritas untuk penyelidikan resmi tentang pelanggaran yang terjadi; (ii) memungkinkan katarsis secara terbuka tentang kejahatan dan penderitaan yang dialami, secara resmi; (iii) memberikan forum bagi para korban dan kerabatnya untuk menceritakan kisah mereka, dan menjadikannya sebagai bagian dari catatan resmi dan dengan demikian pengakuan dari masyarakat tentang penderitaan mereka; dan (iv) dalam

${ }^{3}$ The Administration of Justice and the Human Rights of Detainees: Question of the impunity of perpetrators of violations of human rights (civil and political rights): laporan akhir oleh Louis Joinet menyusul resolusi Sub-komisi 1995/35, UN Doc. E/CN.4/ Sub.2/1996/18 (29 Juni 1996), prinsip 48-50. 
beberapa kasus, memberikan dasar formal untuk kompensasi para korban, ${ }^{4}$ dan penghukuman pelaku. Sebuah ciri standar mandat Komisi Kebenaran adalah menganalisis dan menyusun laporan tidak hanya tentang pelanggaran individual, namun juga konteks luas terjadinya pelanggaran dan elemen struktural pemerintah, pasukan keamanan dan masyarakat yang memungkinkan terjadinya pelanggaran tersebut - yang tidak bisa didapatkan dari peradilan pidana. Dengan penilaian ini, komisi kemudian bertugas untuk menentukan langkah-langkah yang perlu diambil untuk menyikapi pelanggaran di masa lalu dan mencegah perulangannya.

Keunggulan pendekatan Komisi Kebenaran adalah bahwa ia bisa dibentuk dan mulai bekerja dengan segera. Berbeda dengan pengadilan pidana internasional seperti untuk Yugoslavia dan Rwanda, tampak bahwa pengadilan pidana membutuhkan waktu bertahun-tahun untuk mulai bekerja. Demikian pula, dibutuhkan banyak waktu untuk membangun kembali sistem peradilan pidana domestik sehingga dapat mengadili kejahatan perang atau pelanggaran hak asasi manusia yang berat serupa secara kredibel. Sebuah Komisi Kebenaran bisa segera memulai mengadakan dengar pendapat dan mengumpulkan kesaksian dan dokumentasi, yang kemudian bisa dipergunakan dalam pengadilan. Dalam hal ini, komisi penyelidikan bisa memberikan tenggang waktu lebih panjang bagi pengadilan, mengurangi tekanan untuk melakukan tindakan bagi para pelaku kejahatan, selama pengadilan sedang dipersiapkan.

Di pihak lain, berkaitan dengan waktu, mandat Komisi Kebenaran harus realistis dan memberikan waktu cukup bagi komisi tersebut untuk menjalankan tugasnya. Komisi Klarifikasi untuk Guatemala, sebagai hasil kesepakatan damai tahun 1996, memiliki tugas berat untuk menyelidiki "pelanggaran hak asasi manusia dan tindakan kekerasan" yang dilakukan selama masa 36 tahun, ${ }^{5}$ selama perang saudara, yang meninggalkan korban 150 ribu orang tewas atau hilang dan menyebabkan sejuta orang terpaksa mengungsi dari rumahnya. ${ }^{6}$ Komisi tersebut diharapkan untuk

${ }^{4}$ Pendekatan ini digunakan misalnya di Cile. Identifikasi nama seseorang dalam laporan Komisi Kebenaran dan Rekonsiliasi secara otomatis menjadi bukti bahwa seseorang berhak ikut serta dalam program kompensasi. Ini mencegah para korban untuk harus menjalani proses pembuktian lebih lanjut tentang viktimisasi mereka.

${ }^{5}$ Lihat Kesepakatan Pembentukan Komisi Klarifikasi Sejarah Pelanggaran Hak Asasi Manusia dan Tindakan Kekerasan yang Menyebabkan Penderitaan Warga Guatemala (23 Juni 1994) [Kesepakatan Guatemala]

${ }^{6}$ Lihat Larry Rohter, Guatemalans Formally End 36-Year Civil War, Central America's Longest and Deadliest, NY Times, 30 Desember 1996, hlm. A8. 
menghasilkan laporan "informasi objektif tentang apa yang terjadi pada masa ini (termasuk) semua faktornya, baik internal maupun eksternal" memberikan "saran spesifik untuk mempertahankan kenangan tentang para korban, untuk menumbuhkan saling penghargaan dan ketaatan pada hak asasi manusia dan untuk memperkuat proses demokratisasi" ${ }^{7}$ Komisi diberi waktu enam bulan untuk menyelesaikan tugas ini, suatu jangka waktu yang tidak realistis bila diharapkan untuk bekerja dengan serius. Jangka kerja komisi tersebut bisa diperpanjang enam bulan lagi, yang pasti akan diperlukan.

Afrika Selatan menciptakan satu terobosan baru dalam Komisi Kebenarannya. Bertentangan dengan amnesti besar-besaran yang diberikan di berbagai negara Amerika Latin pasca represi, di Afrika Selatan, amnesti diberikan secara individual terhadap pelanggaran yang dilakukan dalam masa apartheid. Untuk mendapatkan amnesti tersebut, seseorang harus mendaftarkan diri dan membeberkan seluruh detil kejahatan mereka kepada Komisi Kebenaran dan Rekonsiliasi ${ }^{8}$ - sebuah insentif yang kuat untuk maju dan membantu kerja komisi. Afrika Selatan tidak sepenuhnya mengandalkan pada amnesti dan komisi kebenaran, namun tetap juga pada pengadilan. Alasan mengapa komisi tersebut berhasil mendorong ribuan orang untuk mengakui kejahatan mereka pada masa apartheid adalah karena pengadilan tetap merupakan ancaman yang nyata. ${ }^{9}$ Seseorang yang tidak memberikan aplikasi amnesti dan memberikan pengakuannya mengalami resiko diadili yang jauh lebih besar, karena banyaknya bukti memberatkan yang didapatkan dari pengakuan orang-orang lainnya. Sejauh mana pengadilan pidana akan dilakukan setelah penutupan aplikasi amnesti masih harus dilihat.

Perlu dicatat bahwa penggunaan Komisi Kebenaran adalah fenomena yang masih relatif baru. ${ }^{10}$ Meskipun sudah diadakan sejumlah penelitian dan analisis tentang mekanisme pertanggungjawaban ini, masih banyak asumsi tentang dampak dan nilai Komisi Kebenaran. Untuk bisa sepenuhnya memahami dampak yang ditimbulkan Komisi Kebenaran,

\footnotetext{
${ }^{7}$ Kesepakatan Guatemala, supra catatan kaki 17.

${ }^{8}$ Lihat Akta Pendorongan Persatuan Nasional dan Rekonsiliasi, Akta 34/1995 (26 Juli 1995), Bab 4.

${ }^{9}$ Hingga akhir bulan Agustus 1997, sudah ada sekitar 7 ribu aplikasi amnesti. Dari aplikasi yang sudah diproses, kira-kira hanya 3 \% yang mendapatkan amnesti. Lihat Pernyataan oleh Dr. Alex Boraine tentang Kerja Komisi, Komisi Kebenaran dan Rekonsiliasi, 20 Agustus 1997.

${ }^{10}$ Komisi Nasional Orang Hilang di Argentina, yang lazim dianggap sebagai komisi kebenaran pertama, dibentuk pada akhir tahun 1983.
} 
perlu lebih banyak penelitian dan pengembangan bukti empiris yang lebih reliabel. Apa dampak Komisi Kebenaran bagi sebagian besar penduduk di negara yang bersangkutan - baik korban, pelaku maupun anggota masyarakat lainnya - yang tidak berpartisipasi dalam penyelidikan komisi itu? Apa dampak jangka panjang komisi kebenaran terhadap pertanggungjawaban dan rekonsiliasi bila kerja komisi tidak disertai pertanggungjawaban pidana? Penyelidikan lebih lanjut dan waktu akan memberikan evaluasi yang lebih reliabel tentang nilai Komisi Kebenaran dibandingkan mekanisme-mekanisme pertanggung-jawaban lainnya.

\section{Upaya di Indonesia}

Seperti halnya pengalaman negara-negara yang telah dipaparkan di atas, tuntutan serupa juga muncul di Indonesia pada masa transisi sekarang. Tuntutan ini berhasil melahirkan UU No 27 tahun 2004 tentang Komisi Kebenaran dan Rekonsiliasi, walau pun pada akhirnya UU ini dibatalkan oleh putusan Mahkamah Konstitusi.

Menarik kita melihat kembali upaya tersebut. Tuntutan yang datang dari korban, pembela hak asasi manusia dan masyarakat pada umumnya itu muncul dalam berbagai manifestasi, salah satunya adalah gagasan pembentukan KKR. Gagasan KKR itu muncul ditengah ramainya publik Indonesia berbicara mengenai pentingnya Rekonsiliasi Nasional. ${ }^{11} \mathrm{Di}$ tengah berbagai gagasan mengenai rekonsiliasi itulah Komisi Nasional Hak Asasi Manusia (Komnas HAM) muncul dengan gagasan KKR, dan mengajukan gagasan ini secara formal ke Presiden BJ Habibie -presiden pertama masa Reformasi. Gagasan ini diartikulasikan lebih lanjut oleh kalangan pembela hak asasi manusia, yang memandangnya sebagai salah satu mekanisme pertanggungjawaban untuk melengkapi pengadilan, bukan menggantikannya.

Tetapi gagasan tersebut tidak sampai berlanjut menjadi kebijakan, baru di masa pemerintahan Abdurrahman Wahid (Gus Dur) pengimplementasian gagasan tersebut mulai dirintis. Menteri Hukum dan Perundang-Undangan kabinet Gus Dur, Yusril Ihza Mahendra, meminta kepada organisasi pembela hak asasi manusia untuk menyiapkan draft RUU KKR. "Karena gagasan

${ }^{11}$ Banyak tokoh cendikiawan yang terlibat membahas isu ini, antara lain, Nurcholish Madjid, Franz Magnis Suseno, Abdurachman Wahid, Mudji Sutrisno, Rudini. Juga dari kalangan pensiunan TNI, seperti Agum Gumelar, yang mengusulkan "Rembug Nasional". 
KKR berasal dari kalangan LSM, diharapkan kalangan LSM dapat menyusun sendiri draft RUU itu. Saya tidak mau mendikte," Menteri Kehakiman memberi alasan. ${ }^{12}$ Setelah menerima draf UU, Menteri Hukum dan Perundang-Undangan lalu membentuk Tim Perumus RUU KKR interdepartemen menyempurnakan draf yang diserahkan kalangan LSM tersebut. Selain itu, untuk menunjukkan keseriusan pemerintahannya dalam menyelesaikan konflik dan pelanggaran hak asasi manusia di masa lalu, Presiden Abdurachman Wahid melakukan kunjungan ke Afrika Selatan membahas dan mempelajari pengalaman Afrika Selatan dalam mengimplementasikan KKR di sana. ${ }^{13}$

Muara dari seluruh usaha yang digambarkan di atas adalah lahirnya Ketetapan MPR No. V/2000 tentang Pemantapan Persatuan dan Kesatuan Nasional. ${ }^{14}$ MPR (sebagai institusi yang merupakan representasi dari kedaulatan rakyat) telah mengeluarkan suatu keputusan politik - yang sekaligus menandakan dicapainya "konsensus nasional" di antara kekuatan-kekuatan politik di dalam masyarakat tentang apa yang harus dilakukan berkaitan dengan pelanggaran berat hak asasi manusia masa lalu - yang harus dilaksanakan oleh Pemerintah dan DPR. Salah satu langkah yang digariskan di dalamnya adalah pembentukan Komisi Kebenaran dan Rekonsiliasi (KKR), yang dapat dikatakan mempercepat proses perumusan draf UU KKR.

Tetapi apa persisnya yang digariskan MPR dalam Ketetapannya tersebut?

“Membentuk Komisi Kebenaran dan Rekonsiliasi Nasional sebagai lembaga ekstra-yudisial yang jumlah anggotanya dan kriterianya ditetapkan dengan undang-undang. Komisi ini bertugas untuk menegakkan kebenaran dengan mengungkapkan penyalahgunaan kekuasaan dan pelanggaran hak asasi manusia pada masa lampau, sesuai dengan ketentuan hukum dan perundang-undangan yang berlaku.

${ }^{12}$ Lihat Kompas, 25 November 1999, “Disiapkan RUU tentang Komisi Kebenaran dan Rekonsiliasi".

${ }^{13}$ Lihat Kompas, 10 April 2000, "Gus Dur dan Presiden Afsel Thabo Mbeki Bahas Komisi Kebenaran dan Rekonsiliasi".

${ }^{14}$ Tetapi penting juga diketengahkan di sini, bahwa sebelum TAP ini lahir telah disebutkan perlunya pembentukkan KKR melalui UU No. 26/2000 tentang Pengadilan Hak Asasi Manusia, dalam pasal 47 angka 1 dan 2, yang isinya sebagai berikut: "pelanggaran hak asasi manusia yang berat yang terjadi sebelum berlakunya undang-undang ini tidak menutup kemungkinan penyelesaiannya dilakukan oleh Komisi Kebenaran dan Rekonsiliasi; Komisi Kebenaran dan Rekonsiliasi sebagaimana dimaksud dibentuk dengan undang-undang". 
Langkah-langkah setelah pengungkapan kebenaran, dapat dilakukan pengakuan kesalahan, permintaan maaf, pemberian maaf, perdamaian, penegakan hukum, amnesti, rehabilitasi, atau alternatif lain yang bermanfaat untuk menegakkan persatuan dan kesatuan bangsa dengan sepenuhnya memperhatikan rasa keadilan dalam masyarakat."

Pembentukan KKR (dalam amanah TAP MPR di atas) dipandang sebagai prerequisite bagi langkah-langkah selanjutnya, yakni berupa: (i) pengakuan kesalahan, (ii) permintaan maaf, (iii) pemberian maaf, (iv) perdamaian, (v) penegakan hukum, (vi) amnesti, (vii) rehabilitasi, atau alternatif lainnya. Inilah "national policy" yang sudah ditetapkan MPR sebagai jawaban terhadap penyalahgunaan kekuasaan dan kekejaman di masa lalu. Menurut wakilwakil rakyat di MPR itu, sebagai akibat dari penyalahgunaan kekuasaan dan pelanggaran hak asasi manusia di masa Orde Baru, ${ }^{15}$ telah timbul bahaya yang kini kita rasakan bersama, yakni ancaman integrasi berbangsa (persatuan dan kesatuan RI) dan konflik horisontal yang meluas. Pembentukan KKR dipandang urgen sebagai salah satu jalan mengatasi masalah nasional tersebut (di aras makro), sekaligus diharapkan dapat menjawab ketidakadilan individual yang dialami para korban (di aras mikro).

Pembentukan Undang-Undang tentang Komisi Kebenaran dan Rekonsiliasi didasarkan pada pertimbangan: (1) Pelanggaran hak asasi yang berat yang terjadi pada masa sebelum berlakunya UU No. 26 Tahun 2000 tentang Pengadilan HAM sampai saat ini belum dipertanggungjawabkan secara tuntas, sehingga korban atau keluarga korban yang merupakan ahli warisnya masih belum mendapatkan kepastian mengenai latar belakang terjadinya pelanggaran hak asasi manusia yang berat terhadap korban. Selain belum mendapatkan kompensasi, restitusi, dan/atau rehabiltasi atas

${ }^{15}$ Berdasarkan analisis TAP MPR V/2000, terjadinya penyalahgunaan kekuasaan di masa lalu disebabkan oleh faktor-faktor, antara lain, sebagai berikut: (i) nilai-nilai agama dan nilai-nilai budaya bangsa tidak dijadikan sumber etika dalam berbangsa dan bernegara; (ii) Pancasila sebagai ideologi negara ditafsirkan secara sepihak oleh penguasa dan telah disalahgunakan untuk mempertahankan kekuasaan; (iii) konflik sosial dan budaya telah terjadi karena kemajemukan suku, kebudayaan, dan agama yang tidak dikelola dengan baik dan adil oleh pemerintah maupun masyarakat; (iv) hukum telah menjadi alat kekuasaan dan pelaksanaannya telah diselewengkan sedemikian rupa sehingga bertentangan dengan prinsip keadilan; dan (v) pelaksanaan peran sosial politik dalam Dwifungsi ABRI dan disalhgunakannya ABRI sebagai alat kekuasaan pada masa Orde Baru telah menyebabkan terjadinya penyimpangan peran TNI dan Polri yang mengakibatkan tidak berkembangnya kehidupan demokrasi. 
penderitaan yang mereka alami, pengabaian atas tanggungjawab ini telah menimbulkan ketidakpuasan, sinisme, apatisme, dan ketidakpercayaan yang besar terhadap institusi hukum karena negara dianggap memberikan pembebasan dari hukuman kepada para pelaku. (2) Penyelesaian menyeluruh terhadap pelanggaran hak asasi manusia yang berat yang terjadi pada masa sebelum berlakunya UU No. 26 Tahun 2000 tentang Pengadilan HAM sangat urgen untuk segera dilakukan karena ketidakpuasan dan ketegangan politik tidak boleh dibiarkan terus berlarut-larut tanpa kepastian penyelesaiannya. (3) Dengan diungkapkannya kebenaran tentang pelanggaran hak asasi manusia yang berat yang terjadi sebelum berlakunya UU No. 26 Tahun 2000 tentang Pengadilan HAM, melalui Komisi Kebenaran dan Rekonsiliasi diharapkan dapat diwujudkan rekonsiliasi nasional.

Di dalam Pasal 1 angka 3 UU No. 27 Tahun 2004 ditegaskan, Komisi Kebenaran dan Rekonsiliasi yang selanjutnya disebut Komisi, adalah lembaga independen yang dibentuk untuk mengungkapkan kebenaran atas pelanggaran hak asasi manusia yang berat dan melaksanakan rekonsiliasi.

Komisi Kebenaran dan Rekonsiliasi dibentuk berdasarkan asas: (a) kemandirian;"16 (b) bebas dan tidak memihak;; (c) kemaslahatan; (d) keadilan; (e) kejujuran; (f) keterbukaan;18 (g) perdamaian; ${ }^{19}$ dan (h) persatuan bangsa.

Komisi berkedudukan di ibukota negara RI dengan wilayah kerja meliputi seluruh wilayah negara RI. Keanggotaan Komisi diperoleh berdasarkan seleksi dan pemilihan dari suatu daftar nominasi yang diajukan oleh perseorangan, kelompok orang, atau organisasi kemasyarakatan. Seleksi

${ }^{16}$ Yang dimaksud dengan "asas kemandirian" adalah suatu asas yang digunakan Komisi dalam melaksanakan tugasnya bebas dari pengaruh pihak manapun. Lihat Penjelasan Pasal 2 huruf a UU No. 27 Tahun 2004.

${ }_{17}^{17}$ Yang dimaksud dengan "asas bebas dan tidak memihak" adalah suatu asas yang digunakan Komisi dalam melaksanakan tugas pengungkapan pelanggaran hak asasi manusia yang berat berdasarkan fakta-fakta yang ada dan tidak diskriminatif. Lihat Penjelasan Pasal 2 huruf b UU No. 27 Tahun 2004.

${ }^{18}$ Yang dimaksud dengan "asas keterbukaan" adalah asas yang memberikan hak kepada masyarakat untuk memperoleh informasi yang benar, jujur, dan tidak diskriminatif tentang segala sesuatu yang berkaitan dengan pelanggaran hak asasi manusia yang berat dengan tetap memperhatikan perlindungan hak asasi pribadi, golongan, dan rahasia negara. Lihat Penjelasan pasal 2 huruf f UU No. 27 Tahun 2004.

${ }_{19}$ Yang dimaksud dengan "asas perdamaian" adalah suatu asas dalam menyelesaikan perselisihan sebagai akibat pelanggaran hak asasi manusia yang berat dilakukan berdasarkan kesepakatan para pihak untuk diselesaikan secara damai, misalnya korban memaafkan pelaku dan pelaku memberikan restitusi kepada korban. Lihat Penjelasan Pasal 2 huruf g UU No. 27 tahun 2004. 
dan pemilihan anggota Komisi didasarkan pada kualifikasi keahlian dan integritas moral yang tinggi dan memenuhi persyaratan, antara lain: (a) memiliki pengetahuan atau kepedulian di bidang hak asasi manusia; (b) tidak berstatus sebagai TNI atau Polri; (c) bersedia melepaskan diri dari keanggotaan partai politik, organisasi kemasyarakatan, atau lembaga swadaya masyarakat; dan (d) tidak pernah terlibat dalam pelanggaran hak asasi manusia. Selain memenuhi persyaratan tersebut, seleksi dan pemilihan anggota Komisi juga harus didasarkan pada pertimbangan geografis, etnis, agama, dan kepakaran.

Anggota Komisi sebanyak 21 (dua puluh satu) orang dengan susunan sebagai berikut: (a) 3 (tiga) orang pimpinan; (b) 9 (sembilan) orang anggota subkomisi penyelidikan dan klarifikasi; (c) 5 (lima) orang anggota subkomisi kompensasi, restitusi dan rehabilitasi; dan (d) 4 (empat) orang anggota subkomisi pertimbangan amnesti.

Komisi mempunyai fungsi kelembagaan yang bersifat publik untuk mengungkapkan kebenaran atas pelanggaran hak asasi manusia yang berat dan melaksanakan rekonsiliasi. ${ }^{20}$ Dalam melaksanakan fungsinya tersebut, Komisi mempunyai tugas: (a) menerima pengaduan atau laporan dari pelaku, korban, atau keluarga korban yang merupakan ahli warisnya; (b) melakukan penyelidikan dan klarifikasi atas pelanggaran hak asasi manusia yang berat; (c) memberikan rekomendasi kepada Presiden dalam hal permohonan amnesti; (d) menyampaikan rekomendasi kepada pemerintah dalam hal pemberian kompensasi dan/atau rehabilitasi; dan (e) menyampaikan laporan tahunan dan laporan akhir tentang pelaksanaan tugas dan wewenang berkaitan dengan perkara yang ditanganinya kepada Presiden dan DPR dengan tembusan kepada MA.

Dalam melaksanakan tugasnya, Komisi mempunyai wewenang: (a) melaksanakan penyelidikan sesuai dengan ketentuan peraturan perundang-undangan; (b) meminta keterangan kepada korban, ahli waris korban, pelaku, dan/atau pihak lain, baik di dalam maupun di luar negeri; (c) meminta dan mendapatkan dokumen resmi dari instansi sipil atau militer serta badan lain, baik yang ada di dalam maupun di luar negeri;

${ }^{20}$ Yang dimaksud dengan "fungsi kelembagaan yang bersifat publik" adalah fungsi pelayanan dan perlindungan kepada masyarakat dengan diberikan wewenang untuk pengungkapan dan pencarian kebenaran atas terjadinya pelanggaran hak asasi manusia yang berat, yang didasarkan kepada kepentingan nasional demi keutuhan dan persatuan bangsa serta tetap utuhnya Negara Kesatuan RI. Lihat Penjelasan Pasal 5 UU No. 27 Tahun 2004. 
(d) melakukan koordinasi dengan instansi terkait, baik di dalam maupun di luar negeri untuk memberikankan perlindungan kepada korban, saksi, pelapor, pelaku, dan barang bukti sesuai dengan peraturan perundangundangan; (e) memanggil setiap orang yang terkait untuk memberikan keterangan dan kesaksian; (f) memutuskan pemberian kompensasi, restitusi, dan/atau rehabilitasi; dan (g) menolak permohonan kompensasi, restitusi, rehabilitasi, atau amnesti, apabila perkara sudah didaftarkan ke pengadilan hak asasi manusia.

Dalam hal tertentu untuk melaksanakan wewenangnya Komisi dapat meminta penetapan pengadilan untuk melakukan upaya paksa. Dalam hal Komisi meminta penetapan pengadilan, maka pengadilan wajib memberikan penetapan dalam jangka waktu paling lambat 7 (tujuh) hari terhitung sejak tanggal permohonan penetapan diterima pengadilan.

Tujuan pembentukan Komisi adalah: (a) menyelesaikan pelanggaran hak asasi manusia yang berat yang terjadi pada masa lalu di luar pengadilan, guna mewujudkan perdamaian dan persatuan bangsa; dan (b) mewujudkan rekonsiliasi dan persatuan nasional dalam jiwa saling pengertian.

Undang-undang tentang Komisi Kebenaran dan Rekonsiliasi secara substansial berbeda dengan ketentuan yang diatur dalam undang-undang tentang Pengadilan HAM. Undang-undang ini tidak mengatur tentang proses penuntutan hukum, tetapi mengatur proses: (1) pengungkapan kebenaran; (2) pemberian kompensasi, restitusi, dan/atau rehabilitasi kepada korban atau keluarga korban yang merupakan ahli warisnya; dan (3) pertimbangan amnesti; yang semua ini diharapkan membuka jalan bagi proses rekonsiliasi dan persatuan nasional.

Berdasarkan fakta-fakta yang ditemukan oleh Komisi Kebenaran dan Rekonsiliasi, pihak yang harus bertanggungjawab atas terjadinya pelanggaran hak asasi manusia yang berat yang terjadi pada masa sebelum berlakunya UU No. 26 Tahun 2000 tentang Pengadilan HAM harus diidentifikasi. Apabila pelaku mengakui kesalahan, mengakui kebenaran fakta-fakta, menyatakan penyesalan atas perbuatannya, dan bersedia meminta maaf kepada korban atau keluarga korban yang merupakan ahli warisnya, pelaku pelanggaran hak asasi manusia yang berat dapat mengajukan permohonan amnesti kepada Presiden. Apabila permohonan amnesti tersebut beralasan, Presiden dapat menerima permohonan tersebut, dan kepada korban harus diberikan kompensasi dan/atau rehabilitasi. Apabila permohonan amnesti ditolak maka 
kompensasi dan/atau rehabilitasi tidak diberikan oleh negara, dan perkaranya ditindaklanjuti untuk diselesaikan berdasarkan ketentuan UU No. 26 Tahun 2000 tentang Pengadilan HAM. Sumber keuangan untuk pembayaran pemberian kompensasi dan/atau rehabilitasi yang menjadi beban negara dibebankan kepada anggaran pendapatan dan belanja negara.

Apabila terhadap pelanggaran hak asasi manusia yang berat telah diputus oleh Komisi Kebenaran dan Rekonsiliasi, maka pengadilan hak asasi manusia ad hoc tidak berwenang memutuskan, kecuali apabila permohonan amnesti ditolak oleh Presiden. Demikian pula sebaliknya, terhadap pelanggaran hak asasi manusia yang berat yang sudah diberi putusan oleh pengadilan hak asasi manusia ad hoc maka Komisi Kebenaran dan rekonsiliasi tidak berwenang memutuskan. Dengan demikian, putusan Komisi Kebenaran dan Rekonsiliasi atau putusan pengadilan hak asasi manusia ad hoc bersifat final dan mengikat.

Materi muatan UU KKR ini meskipun belum sempurna tetapi sesungguhnya merupakan kemajuan yang luar biasa bagi bangsa Indonesia, karena sudah memulai langkah ke arah perwujudan prinsip negara hukum. Beberapa kelemahan UU KKR yang sering menjadi sorotan publik khususnya para aktivis HAM yakni proses rekonsiliasi yang menjadi tujuan akhir dari KKR. Kritik dilontarkan khususnya berkaitan dengan materi muatan Pasal 24 dan Pasal 29 yang berkaitan dengan mekanisme atau proses pemaafan itu sendiri.

Dalam Pasal 24 ditentukan, "Dalam hal Komisi telah menerima pengaduan atau laporan pelanggaran hak asasi manusia yang berat yang disertai permohonan untuk mendapatkan kompensasi, restitusi, rehabilitasi, atau amnesti, komisi wajib memberi keputusan dalam jangka waktu paling lambat 90 (sembilan puluh) hari terhitung sejak tanggal penerimaan permohonan." Pembatasan waktu 90 hari bagi KKR untuk membuat putusan akan memberi kesan kerja KKR yang terburu-buru yang nantinya tidak akan mampu mengungkap kebenaran secara maksimal, sehingga korban akan dirugikan jika dalam waktu tersebut KKR tidak mampu mengungkap kebenaran dengan sebenar-benarnya. Kelemahan lain muncul dalam Pasal 29 yang menegaskan, "Dalam hal pelaku mengakui kesalahan, mengakui kebenaran fakta-fakta, menyatakan penyesalan atas perbuatannya, dan bersedia meminta maaf kepada korban atau keluarga korban yang merupakan ahli warisnya, tetapi korban atau keluarga korban yang merupakan ahli warisnya tidak bersedia memaafkan 
maka Komisi memutus pemberian rekomendasi amnesti secara mandiri dan obyektif. Dalam hal pelaku tidak bersedia mengakui kebenaran dan kesalahannya serta tidak bersedia menyesali perbuatannya maka pelaku pelanggaran hak asasi manusia yang berat tersebut kehilangan hak mendapat amnesti dan diajukan ke pengadilan hak asasi manusia ad hoc." Dengan skenario Pasal 29 tersebut akan menutup kesempatan korban atau ahli waris korban untuk memperoleh kompensasi. Dengan demikian korban tetap dirugikan.

\section{Penutup}

Besar kemungkinannya diperlukan bukan hanya satu mekanisme pertanggungjawaban untuk bisa menjadi solusi yang optimal. Tantangannya adalah untuk menentukan kombinasi yang paling tepat: Komisi kebenaran yang diikuti pengadilan seperti di Argentina?; Pengadilan domestik dan internasional, seperti Rwanda?; Pengadilan untuk beberapa tokoh dan sanksi administratif bagi lainnya seperti pada transisi pasca-Perang Dunia Kedua dan pasca-komunis? Pada akhirnya, tidak ada solusi mekanistis yang seragam yang bisa diterapkan pada semua kasus. Dengan bantuan komunitas internasional, setiap masyarakat yang baru saja melangkah keluar dari genosida, kejahatan perang atau kejahatan terhadap kemanusiaan akan memerlukan pendekatan atau kombinasinya yang spesifik untuk mendapatkan keadilan dan rekonsiliasi yang optimal.

\section{Daftar Pustaka}

M. Cherif Bassioni, Post-Conflict Justice (New York: Transnational Publishers, 2002)

Kesepakatan Umum tentang Perdamaian di Bosnia dan Herzegovina, 14 Desember 1995, Lampiran 7, pasal I, paragraf 3(e), dalam 35 ILM 75, 137

The Administration of Justice and the Human Rights of Detainees: Question of the impunity of perpetrators of violations of human rights (civil and political rights): laporan akhir oleh Louis Joinet menyusul resolusi Subkomisi 1995/35, UN Doc. E/CN.4/Sub.2/1996/18 (29 Juni 1996), prinsip 48-50

Kesepakatan Pembentukan Komisi Klarifikasi Sejarah Pelanggaran Hak Asasi Manusia dan Tindakan Kekerasan yang Menyebabkan 
Penderitaan Warga Guatemala (23 Juni 1994) [Kesepakatan Guatemala]

Larry Rohter, Guatemalans Formally End 36-Year Civil War, Central America's Longest and Deadliest, NY TIMES, 30 Desember 1996,

Akta Pendorongan Persatuan Nasional dan Rekonsiliasi, Akta 34/1995 (26 Juli 1995)

Kompas, 25 November 1999, “Disiapkan RUU tentang Komisi Kebenaran dan Rekonsiliasi"

Kompas, 10 April 2000, “Gus Dur dan Presiden Afsel Thabo Mbeki Bahas Komisi Kebenaran dan Rekonsiliasi"

UU No. 26 Tahun 2000 tentang Pengadilan Hak Asasi Manusia,

TAP MPR V Tahun 2000 tentang Pemantapan Persatuan dan Kesatuan Nasional

UU No. 27 Tahun 2004 Komisi Kebenaran dan Rekonsiliasi 